\title{
The Effects of Recreational and Sports Activities on Psychological Status in Young People Aged 11-13 Years
}

\author{
Yener Aksoy $^{1, *}$, Soner Çankaya ${ }^{2}$, M. Yalçın Taşmektepligil ${ }^{3}$ \\ ${ }^{1}$ Vezirköprü Provincial Directorate of Youth Services and Sports, Turkey \\ ${ }^{2}$ Department of Biostatistics and Medical Informatics, Faculty of Medicine, Ordu University, Turkey \\ ${ }^{3}$ Yaşar Doğu School of Sports Sciences, Ondokuz Mayıs University, Turkey
}

Copyright $\odot 2017$ by authors, all rights reserved. Authors agree that this article remains permanently open access under the terms of the Creative Commons Attribution License 4.0 International License

\begin{abstract}
This study was conducted to investigate the depressive state and loneliness in a total of 219 male adolescents between the ages 11 and 13 who were registered at the summer school of the Vezirköprü Provincial Directorate of Youth Services and Sports based on whether or not they participated in recreational and sports activities during the summer holiday. One hundred and fifteen of the participants participated in recreational and sports activities organized during the summer, while 104 did not. Information about the depressive states of the participants was collected via the Beck Depression Scale, while information about their loneliness was collected with the UCLA Loneliness Scale. High total scores on both scales indicated that depression and loneliness levels were high. The Cronbach's alpha internal consistency coefficient was calculated to determine the reliability of the answers given by the participants to the items of Beck Depression Scale and UCLA-LS. In the statistical assessment of the research results, it was found that the error terms were not normally distributed $(\mathrm{P}<0.05)$. Thus, the differences between the group that participated in recreational activities and the group that did not were shown via a Mann-Whitney U-test. In addition, the association between the total scores on both scales was calculated using Kendall's tau b correlation coefficient. At the end of the study, the Beck Depression scores of the adolescents who did not participate in any recreational or sports activities during the summer holiday (13 weeks) were found to be significantly higher than the scores of those who did. Thus, while the depression levels of individuals who did not participate in recreational or sports activities were high, the levels of individuals who regularly participated in these activities were low. Similarly, the loneliness scores of individuals also differed based on participation in these activities. The loneliness scores of adolescents who did not participate in the related activities were found to be significantly higher than those who did. In short, the reason for these low levels of depression and loneliness following participation in sports activities is understood to result directly from participation in these activities. Also, a
\end{abstract}

strongly positive significant association was found between the Depression and Loneliness Scale scores of adolescents who did engage in sports. An increase was seen in the Beck Depression scores of the participants as their loneliness scores increased. In other words, as Beck Depression scores increase, so do the levels of loneliness. Thus, engaging in regular recreational and sports activities over extended periods of time can be said to be effective in eliminating the depressive and lonely feelings of adolescents. Educational institutions should include such programs within regular education.

Keywords Recreation, Sports Activity, Depression, Loneliness

\section{Introduction}

The culture of exercise, which has a past that goes back to the beginning of human history, has attracted attention as an important part of social life and continues to maintain its importance, attaining new meanings in people's daily lives depending on economic conditions, industrialization, urbanization, increases in free time, personal health concerns, etc. Recent innovations in industrial societies affect these societies not only economically but also in other areas of life, sometimes making individuals slaves of modernism. Thus, in today's world, where technology plays in increasingly important role in people's lives, a more sedentary life is gradually coming to be preferred, and individuals' social and psychological health are thus placed at considerable risk.

Depression, one of the two concepts addressed in this study, is defined as an instantaneous mood involving emotional collapse. It has been the main focus of clinical reviews and research projects in psychiatry over the last 30 years. There is no doubt that anyone can experience an emotional collapse (depression) because of the situation 
they are in. Situations such as contradictory/conflicting situations, loneliness, the loss of a loved one, quitting one's job, marital conflicts, receiving low grades on exams or not getting what one wants can cause emotional collapse [1]. Also, individuals' relationship problems can cause them to isolate themselves from society and become lonely [2]. The distinct characteristics of depression can be summarised as follows: loneliness; increased feelings of sadness and unwillingness; feelings of unworthiness, together with self-accusation and humiliation; a tendency toward self-punishment, avoiding social relationships and withdrawal; a lack of sexual drive; an obvious decrease in physical energy and the wish to die, sometimes by committing suicide [3].

Loneliness, a painful feeling like depression, can be defined as a state of feeling lonely while being with other people, without any objective reason. This feeling results from a person's existing relationships not meeting his or her expectations [4].

Today, especially among adolescents, depression and loneliness occur frequently, and these moods can cause adolescents to engage in negative behaviors that threaten their health. There is no doubt that one of the ways to overcome negative feelings is for a person to change his or her lifestyle and participate in sports-based recreational activities. Exercise is a form of medication that enables changes in consciousness and improved relaxation and prevents anxiety and stress [5].

In fact, recreational activities have very important and undeniable benefits in terms of increasing individuals' quality of life and moving social relationships in a healthy direction. Within this framework, sports and recreational games are a means of maintaining healthy social tendencies. What we now call games and carefully distinguish are among the oldest human activities [6]. In this sense, such activities are social behaviors that appeal to the body and the soul, and in this respect, games involve self-discipline, experience, self-expression, self-realisation and physical boundaries [7].

Participating in recreational activities is known to decrease nervousness and provide psychological well-being. Thus, recreational activities are among the treatment methods used in psychiatric rehabilitation programs. Physical activities can increase individuals' capacities to cope with stress and adapt to new conditions [8]. In addition, sports activities provide a perfect opportunity for communication. As an educational activity, they also develop individuals' abilities to cooperate with one another. Thus, such activities can be said to have significant effects on social integration.

Based on the above information, the purpose of this study is to determine how adolescents' feelings of depression and loneliness change when they engage in recreational activities during the summer holiday (13 weeks) and thus understand how effective such activities are in terms of making society more dynamic.

\section{Materials and Methods}

This study was conducted on a total of 219 male adolescents between the ages of 11 and 13 who were registered at the summer school of the Vezirköprü Provincial Directorate of Youth Services and Sports, a touristic town of Samsun in the Middle Black Sea Region of Turkey, and volunteered to participate in the study. The individuals who formed the sample were first divided as randomly in two groups: the experimental $(\mathrm{n}=115)$ and control groups $(n=104)$. While the control group did not participate in any activities during the summer, the experimental group regularly participated in recreational activities, such as cinema, music, art, scouting and sports activities such as football, volleyball, taekwondo, wrestling, tennis and basketball.

In this study, the Beck Depression Scale and UCLA Loneliness Scale were used as data collection tools. The Beck Depression Scale (BDS), which was used to determine the depression levels of the participants (experimental and control groups) has 21 items, and each item is scored between 0 and 3. In order to determine the severity of an individual's depression, his or her total score should be compared with certain critical values. These critical values have been defined as 1-10 for 'normal', 11-16 for the 'lowest level' of depression, 17-20 for a 'mild level' of depression, 21-30 for a 'moderate level' of depression, 31-40 for 'severe depression' and 41-63 for 'very severe depression' [9]. The UCLA Loneliness Scale, which was developed by Russel et al. to determine the level of loneliness perceived by individuals [10] and adapted by Demir [11], has 20 items, ten of which are directly coded and ten of which are reversely coded, and it is a 4-point Likert-type scale. Because the scores for each item range between 1 and 4, the lowest score one can receive on the scale is 20 , while the highest score one can receive is 80 . High scores indicate high levels of loneliness.

\subsection{Statistical Analysis}

In the study, the Cronbach's alpha internal consistency coefficient was calculated to determine the reliability of the answers given by the participants to Beck Depression and UCLA-LS (Loneliness) scales. According to the Kolmogrov-Smirnov (for $\mathrm{n} \geq 50$ ) test results for the scores on both scales, the error terms were not found to be normally distributed $(\mathrm{P}<0.05)$. Thus, the differences between the total scores of adolescents who participated in recreational activities and those who did not participate in recreational activities were shown via a Mann-Whitney U-test. In addition, the association between the total scores on both scales was calculated with Kendall's tau b correlation coefficient.

In order to show the results, the frequency (n), mean $(\bar{x})$, standard deviation (SD), median, IQR (interquartile range) and minimum and maximum values were used as descriptive 
statistics. The results were accepted as significant at the level of $P<0.05$. All the statistical calculations were made with the SPSS 22.0 statistical program.

\section{Results}

As a result of the reliability analysis (Cronbach's Alpha) that was conducted to show the internal consistency of the answers participants gave, the reliability coefficient of the Beck Depression Scale was found to be 0,926 , while the reliability coefficient of the UCLA Loneliness Scale was found to be 0.712 . These values are higher than 0.70 , which is considered to indicate sufficient reliability [12].

The total Beck Depression scores of all the adolescents who participated in the study were found to be generally low. However, Beck Depression total scores of the individuals who participated in sports and recreational activities were statistically significantly different from those of the individuals who did not participate in sports and recreational activities $(P=0.005)$. While the Beck Depression levels (12.07) of those who did not participate in activities were at the minimum-depression level, the levels of those who participated in activities (9.36) were within the normal limits. When the total loneliness scores of the adolescents were considered in a general way, these scores were found to be a bit higher than the depression scores. The loneliness levels of the individuals who participated in sports and recreational activities were found to be significantly lower than those who did not participate $(\mathrm{P}=0.001)$ (Table 1). These results show that participation in the related activities is the reason why the depression and loneliness levels of these individuals were low. Thus, with this study, it was shown that sportive activities help individuals who feel lonely and who are inclined to depression can communicate more easily with the society.

On the other hand, in terms of the scores individuals received on the Beck Depression and UCLA Loneliness Scales, positive significant associations were found between these two scores among those who participated in sports and recreational activities at a rate of $92.9 \%$, as well as at a rate of $84.6 \%$ among those who did not participate and at a rate of $85.4 \%$ among all participants. Thus, increases in Beck
Depression and Loneliness Scale scores influence one another directly. That is, as the participants' loneliness scores increase, there is also an increase in their depression scores. Conversely, as Beck Depression scores increase, so do loneliness scores.

\section{Discussion and Conclusions}

The need for movement attracts people to sports and recreational activity centers [13]. In addition to their value as performance, sports are increasingly important in quality of life [14].

The purpose of this study was to determine the extent to which changes in depression and loneliness among adolescents were influenced by recreational and sports activities. Frequent psychological health assessments report that the most frequently seen psychological disease is depression [15], and the World Health Organization (WHO) states that between $3 \%$ and $5 \%$ of the world's population has some kind of depressive complaint [16]. According to studies, the group that most commonly experiences depressive mood as a psychological disorder is adolescents [17-19]. During their high school experience, adolescents must confront many challenges, such as adapting to the environment, obtaining a place in society and finding one's own identity. As a result of this, they may be more sensitive than adults when assessing the events of their lives [20]. This sensitivity may to explain why adolescents experience more problem than adults. In this study, the total Beck Depression scores of the individuals who participated in recreational activities were statistically significantly different than those who did not $(P=0.005)$. According to these results, while no depression was found in adolescents who participated in recreational and sportive activities, only the lowest level of depression was found in those who did not participate. Since the subjects were divided randomly at the beginning of the study, it is assumed that the subjects in both groups have similar or equal depression and loneliness scores. Thus, it can be said that the difference between measurements results from sportive activities at the 0.05 level according to type I error.

Table 1. Beck Depression and UCLA Loneliness levels of the participants

\begin{tabular}{|c|c|c|c|c|c|c|c|c|}
\hline Groups & $\mathrm{N}$ & Mean & $\mathrm{SD}$ & Median & IQR & Min & Max & P-Value \\
\hline \multicolumn{9}{|c|}{ Beck Depression Scale Scores } \\
\hline Non-recreation group & 104 & 12.07 & 11.18 & 7.00 & 13.00 & 0 & 39 & \multirow{2}{*}{0.005} \\
\hline Recreation group & 115 & 9.36 & 11.08 & 6.00 & 13.00 & 0 & 38 & \\
\hline \multicolumn{9}{|c|}{ UCLA Loneliness Scale Scores } \\
\hline Non-recreation group & 104 & 52.26 & 6.47 & 52.00 & 8.00 & 27 & 67 & \multirow{2}{*}{$<0.001$} \\
\hline Recreation group & 115 & 47.75 & 9.22 & 50.00 & 9.00 & 20 & 68 & \\
\hline
\end{tabular}


When the association between recreational and sports activities and depression was examined, it was found that many studies put forward the notion that regular activities are useful in combating depressive mood disorders and state that regular recreational activity, such as aerobic exercises, were useful in maintaining mental health of individuals [21, 22].

Thus, in the treatment of low and moderate levels of depression, which is among the most common diseases of our day, regular moderate exercise can be used both directly and in a complementary way. In addition, moderate sports and creative activities are reported to be an important way of reducing and preventing depression. In fact, they are reported to be as effective as drugs in treatment $[23,24]$. The results of this study are similar to those mentioned above.

In assessments of psychological health, loneliness, like depression, is a mood change that has attracted a great deal of attention. Loneliness is a common and unpleasant experience that occurs when a person's network of social relationships is significantly deficient in either quality or quantity [25]. Loneliness is a potent but little-understood risk factor that is experienced by all age groups, but it is most prevalent among adolescents. In the literature, loneliness is seen to occur as a result of both personal development factors and the influence of social interactions with the environment, and it is reported to be associated with shyness, social anxiety, self-respect and demographic variables [27]. Studies show that the feeling of loneliness occurs very frequently among adolescents and young adults, as opposed to during old age [28-30].

Adolescence is accepted as an ideal developmental period during which to research the subject of loneliness. The developmental changes that make adolescents prone to loneliness are very important because young people can have identity crises during this period and also because young people's relationship with their friends is more important than their relationships with their parents [4]. Thus, there is a very strong connection between adolescence and loneliness. When the loneliness score results were assessed in this study, the data were found to support this view. When the total average loneliness scores of all the young people who participated in the activities $(\bar{x}=47.75)$ and those who did not ( $\bar{x}=52.26)$ were compared, they were found to be very high in general. Also, the loneliness levels of the individuals who participated in recreational activities were found to be significantly lower when compared with those who did not participate in recreational activities $(\mathrm{P}=0.001)$ (Table 1). As can be understood from the results, recreational and sports activities are effective in combatting loneliness in adolescents. Some researchers have shown that certain activities, such as listening to music, watching television and playing sports, are among the methods used by adolescents from rural areas and university students in coping with loneliness $[31,32]$.

On the other hand, a positive and highly significant association was found between individuals' states of depression and loneliness. These were found to be associated in $92.9 \%$ of the individuals who played sports and in $84.6 \%$ of individuals who did not play sports. Thus, high depression and loneliness scale scores influence one another in a positive way. That is, as the participants become lonelier, an increase in their depressive feelings can be seen. Conversely, as individuals' levels of depression increase, their loneliness also increases.

\section{Suggestions}

- Students should be told about depression and loneliness during their education, and they should be given basic information about how to use their free time to decrease these feelings.

- Municipalities serving the local people should increase public awareness of sports and social and recreational activities, and they should create organisations devoted to these issues.

- Because regular sportive and recreational activities can be used among various age groups to decrease feelings of depression and loneliness, they should be addressed in primary, secondary and university education.

- In addition to efforts to avoid social events that cause depression and loneliness, the skills needed for coping with the problems that cause hopelessness should be taught to adolescents, especially those living in families with low socioeconomic status.

\section{REFERENCES}

[1] C. Tugrul, MA. Sayılgan. Depresyonla Başa Çıkma Yolları (3. bask1). Ankara: Türk Psikologlar Derneği. 1997.

[2] M. Buluş. Üniversite Öğrencilerinde Yalnızlık”, Pamukkale Üniversitesi Eğitim Fakültesi Dergisi, Vol. 3: 82-90, 1997. http://dergipark.ulakbim.gov.tr/esosder/article/view/5000068 662

[3] AT. Beck, YA. Rush, FB. Show, G. Emery. Cognitive Therapy of Depression. New York, Guilford Pres. 1979. https://www.ncbi.nlm.nih.gov/pubmed/11982560

[4] M. Eskin. Ergenlikte yalnızlık, baş etme yöntemleri ve yalnızlığın intihar davranışı ile ilişkisi, Klinik Psikiyatri. Vol. 4: 5-11, 2001. http://www.klinikpsikiyatri.org/jvi.aspx?pdir= kpd\&plng=tur\&un=KPD-00461

[5] BC. Long. Aerobic conditioning and stress reduction: participation or conditioning? Human Movement Science, Vol. 2: 171-186, 1983.

https://www.mysciencework.com/publication/show/5b66126 d908ddac98719bf0268253c77

[6] B. Gillet. Spor Tarihi, Gelişim Yayınları, İstanbul, 1975. 
[7] D. Voigt. Spor Sosyolojisi, (Çev: Ayşe Atalay), Alkım Yayınları, İstanbul, 1988.

http://www.kitapyurdu.com/kitap/spor-sosyolojisi/62964.htm 1

[8] PM. Morgan, JA. Roberts, AD. Feinerman. Psychological effect of acute physical activity, Archives of Physical Medicine Rehabilitation. Vol. 52: 422-425, 1971.

[9] T. Ahmadipour, F. Avand, S. Mo'menpour. Bibliotherapy on depressed university students: A case study. Studies in Literature and Language. Vol. 4, No. 2, 49-57, 2012. http://cscanada.net/index.php/sll/article/view/j.sll.192315632 0120402.1900/4144

[10] D. Russell, LA. Peplau, ML. Ferguson. Developing a measure of loneliness. Journal of Personality Assessment. Vol. 42, 290-294. 1978.

https://www.ncbi.nlm.nih.gov/pubmed/660402

[11] A. Demir. UCLA LS Yalnızlık ölçeğinin geçerlilik ve güvenirlilik çalışması, Psikiyatri, Psikoloji ve Psikofarmakoloji Dergisi. Vol. 1, 2-51, 1993.

[12] R. Altunışık, R. Coşkun, S. Bayraktaroğlu, E. Yıldırım. Sosyal Bilimlerde Araştırma Yöntemleri SPSS Uygulamalı. Sakarya Yayıncılık. Sakarya, 2007. http://dergipark.gov.tr/makusobed/issue/24658/260819

[13] MY. Taşmektepligil, Ö. Bostancı .Farklı özelliklere sahip fertlerin sportif faaliyetlere katılımlarını etkileyen faktörlerin belirlenmesi, Gazi Beden Eğitimi ve Spor Bilimleri Dergisi. Vol. 5, No. 2, 26-42, 2000

http://dergipark.gov.tr/download/article-file/286153

[14] Z. Koruç, P. Bayar. Egzersizin depresyon tedavisindeki yeri ve etkileri, Spor Bilimleri Dergisi. Vol. 15, No. 1, 50-61, 2004. http://hacettepe.dergipark.gov.tr/download/article-file/151371

[15] N. Yüksel. Bilişsel işlevleri yönünden normallerle depresif hastaların karşılaştırılması. Psikoloji Dergisi, Vol. 5, No. 117, 14-15, 1984.

[16] M. Haefly. Focus on Depression. Basel, 1990.

[17] MH. Özbay, N. Şahin, G. Hınçal, S. Güngör, E. Öztürk Kılıç, A. Mavili Aktaş, M. Aybaş, E. Göka (). Ergenlikte benlik imajı: Çalışan ve öğrenci ergenler arasında karşılaştırmalı bir çalışma, Türk Psikiyatri Dergisi. Vol. 2, No. 2, 82-95, 1991.

[18] M. İdiğ. Adolescent's Evaluation of Families' Well Being And It's Relationship to Parent's Marital Satisfaction, Adolescent's Self Concept and Depression. Yayımlanmamış yüksek lisans tezi, İstanbul Üniversitesi. İstanbul, 1990.

[19] R. Okucu. Ergenlik Çağı İntihar Girişimlerinde Psikososyal Etmenler, Çocuk Sağlığı Enstitüsü, Yayımlanmamış yüksek lisans tezi. İstanbul Üniversitesi, 1988.

[20] N. Ören, B. Gençdoğan. Lise öğrencilerinin depresyon düzeylerinin bazı değişkenlere göre incelenmesi, Kastamonu Eğitim Dergisi. Vol. 15, No. 1, 85-92, 2007. http://www.kefdergi.com/pdf/15_1/85.pdf
[21] JA. Blumenthal, S. Williams, TL. Needels, AG. Wallace. Psychological changes accompany aerobic exercise in healthy middle-aged adults, Psychosomatic Medicine. Vol. 44, 529-535, 1982.

https://www.ncbi.nlm.nih.gov/pubmed/7163456

[22] M. Babyak, JA. Blumenthal, S. Herman, P. Khatri, M. Doraiswamy, K. Moore, WE. Craighead, TT. Baldewicz, KR. Krishnan. Exercise treatment for major depression: maintenance of therapeutic benefit at 10 months, Psychosom Med. Vol. 62, No. 5, 633-638, 2000.

https://www.ncbi.nlm.nih.gov/pubmed/11020092

[23] AL. Dunn, MH. Trivedi, JB. Kampert, CG. Clark, HO. Chambliss. Exercise treatment for depression: efficacy and dose response, Am J Prev Med. Jan; Vol. 28, No. 1, 1-8. 2005. https://www.ncbi.nlm.nih.gov/pubmed/15626549

[24] E. McAuley, GJ. Jerome, DX. Marquez, S. Elavsky, B. Blissmer. Exercise self-efficacy in older adults: social, affective, and behavioral influences. Ann Behav Med. Winter, Vol. 25, No.1, 1-7, 2003.

https://www.ncbi.nlm.nih.gov/pubmed/12581930

[25] D. Perlman, LA. Peplau. Loneliness research: survey of empirical findings, in: LA. Peplau and SE. Goldston (Eds) Preventing the Harmful Consequences of Severe and Persistent Loneliness (Washington, DC, US Government Printing Office. Preventing the harmful consequences of severe and persistent loneliness, 1984.

[26] A. Salimi, B. Jowkar. Personality predispositions and loneliness in adolescence, Procedia-Social and Behavioral Sciences. Vol. 29: 269-299, 2011.

http://www.sciencedirect.com/science/article/pii/S187704281 1027030

[27] A. Erözkan. Ergenlerde yalnızlığın yordayıcıları. İlköğretim Online, Vol. 8, No. 3, 809-819, 2009. http://ilkogretim-online.org.tr.

[28] WH. Jones, MD. Carver. Adjustment and Coping Implications of loneliness, R Snyder and D.R. Forsyth (Eds.), Handbook of Social and Clinical Psychology: The Healthy Perspective (395-415) New York: Pergamon press, 1991.

[29] T. Brennan. Loneliness at adolescences. Loneliness: A Sourcebook of Current Theory, Research and Therapy, Peplau L, Perlman D (Eds.), New York, John Wiley, 1982.

[30] Williams EG. Adolescent loneliness. Adolescence, Vol. 18, 51-66, 1983.

http://search.proquest.com/openview/d49a67ecdae980150032 $54 \mathrm{cc} 1 \mathrm{~b} 95 \mathrm{e} 6 \mathrm{~b} 0 / 1$ ?pq-origsite $=$ gscholar $\& \mathrm{cbl}=1819054$

[31] JC. Woodward, BD. Frank. Rural adolescent loneliness and coping strategies. Adolescence, Vol. 23, 559-565, 1988. http://search.proquest.com/openview/db1bc56941e80d00d09 9aa26c9cc258d/1?pq-origsite $=$ gscholar $\&$ cbl $=1819054$

[32] B. Roscoe, GG. Skomski. Loneliness among late adolescents, Adolescence. Vol. 24, 947955, 1989. http://search.proquest.com/openview/e42ce6f5ccc91d240229 $21606 \mathrm{e} 6 \mathrm{e} 6 \mathrm{fbb} / 1$ ?pq-origsite $=$ gscholar $\& \mathrm{cbl}=1819054$ 